\title{
IoT based Human Guided Smart Shopping Cart System for Shopping Center
}

\author{
Shivika Srivastava ${ }^{1}$, Shivansh Rai $^{1}$, Shashi Kumar ${ }^{1}$, Shippu Bhuhsan ${ }^{1}$, Devasis Pradhan $^{2 *}$ \\ ${ }^{1}$ Final Year UG Students, Department of Electronics \& Communication Engineering, Acharya Institute of Technology, Dr. Sarvepalli Radha Krishnan \\ Road, Bengaluru -560107, India \\ ${ }^{2}$ Assistant Professor, Department of Electronics \& Communication Engineering, Acharya Institute of Technology, Dr. Sarvepalli Radha Krishnan Road, \\ Bengaluru -560107, India
}

\author{
DOI: $10.36348 /$ sjet.2020.v05i06.004 \\ | Received: 18.06.2020 | Accepted: 25.06.2020 | Published: 28.06.2020 \\ *Corresponding author: Devasis Pradhan
}

\section{Abstract}

Nowadays, supermarkets are almost developed with much technological advancement. People purchase different items from the supermarkets and put them into a trolley because it is the easiest method used in supermarkets to carry goods. However, throughout the whole process of shopping, customer must push the trolley manually by their own effort and when it comes to the billing process customers must wait in long queues to pay their bills. This is a time wasting process due to the busy schedule of people. To avoid these problems the research groups have introduced an effective and highly advance system. To swamp these problems, Shopping malls use this technique as a strategy to increase the number of purchasers. In big cities, we can observe an enormous flash at shopping malls on weekends. This becomes even more when there is diversity of offers and discount. The prevailing billing system is a bit time consuming. So, we thought of inventing a remedial electronic product to catch-up with this problem. We call it "Human Guided Smart Cart for billing system".

Keywords: Supermarkets, Trolley, Billing; Arduino Card; RFID Tags; Smart Cart, Wireless communication; QR Code.

Copyright @ 2020: This is an open-access article distributed under the terms of the Creative Commons Attribution license which permits unrestricted use, distribution, and reproduction in any medium for non-commercial use (NonCommercial, or CC-BY-NC) provided the original author and source are credited.

\section{INTRODUCTION}

Technology is considered to be extremely important in business because it provides faster and more efficient methods of getting a job done. The development of technology has led to so many mindblowing discoveries, better facilities, and better luxuries, but at the same has dramatically changed our daily lives. Day to day life of an ordinary human being has become a lot more hectic and people actually do not have much time to spend for shopping which is an inevitable thing. That is why people prefer shopping in the malls so that they can get all the products at the same place. But what if we can reduce the time spent on shopping by our new idea [1-3].

Our new idea is "Human Guided Smart Cart". The concept is designed into a smaller version of the automated self-checkout system on a shopping trolley with a user interface screen which allows customers to make payment for items scanned and placed in the trolley before leaving the exit of the store. This is to release pressure at the tills during peak hours $[4,5]$.
The Smart Cart comes with all the traditional services including scanning an item to check for price and details, also there are other additional features that will be included in the design such as locating an item in the store by typing in the item's name in the search field on the user interface screen which will automatically show the item's location in the store. The Smart Cart is designed for an efficient billing system and also to reduce time wasted in long queues [6].

The Smart Cart idea is based on the most popular automated self-checkout system in UK retail stores. The Smart Cart is designed with security measures to prevent it being wheeled out from the store, and payment is done via QR code [7]. This system mainly use the techniques such as barcodes, QR codes, NFC technology combined with RFID in the scanner that detects the bar code and sends the information to the supermarket database. The application keeps adding the items and computing the cost and the list is updated accordingly [8]. Once the payment process is done, data will be updated in the database and receipt will be printed, it will reduce the long waiting queue in front of the counter, thus saving the time of customers for a very 
enjoyable shopping experience [9].

\section{LITERATURE SURVEY}

An automatic line following trolley, this trolley is being guided behind the customer with use of traditional line following techniques. Considering the functional facts that they developed, the research group developed an automated trolley which follows the customer with use of an Arduino mega to ride the trolley the research group came up with the methodology sensors to track the path which the customers walks. Moreover, the developed research consists of a tablet which is fixed in front of the trolley to track the goods which the customers purchased and automatic billing system which is developed with use of Android operating system. The brief description of Literature survey is shown in Table-1.

Table-1: Literature Survey

\begin{tabular}{|l|l|l|l|l|}
\hline $\begin{array}{l}\text { Sl. } \\
\text { No }\end{array}$ & YEAR & TITLE & AUTHOR & ANALYSIS \\
\hline $\mathbf{1}$ & $\mathbf{2 0 1 6}$ & $\begin{array}{l}\text { RFID Based } \\
\text { Wireless } \\
\text { Intelligent Cart } \\
\text { Using ARM7 }\end{array}$ & $\begin{array}{l}\text { Suraj. S, Vishal Guruprasad, } \\
\text { Udayagiri R Pranava, } \\
\text { Preetham S Nag }\end{array}$ & $\begin{array}{l}\text { They have explored an automatic identification by using } \\
\text { RFID that helps to benefit the quality of service provided by } \\
\text { the retailers. Besides, ZigBee, IR sensor module will be used } \\
\text { to transfer the billing data to the counter computer to detect a } \\
\text { selected light wavelength in the infrared spectrum. }\end{array}$ \\
\hline $\mathbf{2}$ & $\mathbf{2 0 1 7}$ & $\begin{array}{l}\text { Smart Shopping } \\
\text { Cart }\end{array}$ & $\begin{array}{l}\text { Akshay Kumar, Abhinav } \\
\text { Gupta, S. Balamurugan, S. } \\
\text { Balaji, R Marimuthu }\end{array}$ & $\begin{array}{l}\text { This paper is targeted to reduce the Queue at a billing } \\
\text { counter and uses arduino module and Xbee modules for } \\
\text { testing of the hardware. }\end{array}$ \\
\hline $\mathbf{3}$ & $\mathbf{2 0 1 7}$ & $\begin{array}{l}\text { Smart Trolley } \\
\text { using arduino } \\
\text { and smart phone }\end{array}$ & $\begin{array}{l}\text { Harpreet Singh Bedi*, Nikhil } \\
\text { Goyal, Sunil Kumar And } \\
\text { Avinash Gupta }\end{array}$ & $\begin{array}{l}\text { This paper provided us with future endeavors of the product } \\
\text { and motivation for the same by using RFID im membership } \\
\text { cards of the customers, there by a good security module for } \\
\text { the trolley. }\end{array}$ \\
\hline $\mathbf{4}$ & $\mathbf{2 0 1 8}$ & $\begin{array}{l}\text { Smart Trolley } \\
\text { for a Smart } \\
\text { Shopping }\end{array}$ & $\begin{array}{l}\text { Renjini Jose, Saleh Musallam } \\
\text { Abdullah Al Harthi, Ahmed } \\
\text { Abdullah Awadh Koofan, } \\
\text { Aida Khamis Ahmed Al Raiisi }\end{array}$ & $\begin{array}{l}\text { This paper carried out a survey regarding the difficulties in } \\
\text { traditional shopping system and concluded that if this smart } \\
\text { system is implemented in hypermarkets, it will reduce the } \\
\text { long waiting queue in front of the counter, thus saving the } \\
\text { time of customers for a very enjoyable shopping experience }\end{array}$ \\
\hline
\end{tabular}

\section{Proposed System - IoT Based Shopping Cart with Smart Technology}

In this paper, we are going to develop an interactive smart trolley system by using RFID modules. This system not only allows the user to use the real-time spending feedback with the budget detection system on the trolley but also manage to interact it with the web application. Basically to ensure automation of the system, customer will initiate the process by clicking on a 'START BUTTON' and followed by scanning the product.

A scanner is connected to the base station located at the payment counter. When a customer scans a product, all the information such as and name of the product is displayed while the weight of the product is stored in the database. It uses NFC technology combined with RFID in the scanner that detects the bar code and sends the information to the supermarket database. The application keeps adding the items and computing the cost and the list is updated accordingly. There is an option for a customer to remove the product again by rescanning it.
A load cell, which is basically a load sensor, is located on the trolley helps in decision making against abnormal activities and discrepancy. Smart Trolley ensures security measures by considering special cases and giving its solutions.

These cases are mentioned below:

- A customer forgets to keep a product into the trolley after scanning it.

- A customer scans one product but places multiple products in the trolley.

- A customer attempts to take away products in the trolley without scanning them.

- A load cell, which is basically a weight sensor, is located at the bottom of the Smart Trolley.

The output of the load cell helps in decision making against abnormal activities. For example, if the weight of the product measured by the load cell is not matching with the actual weight of the product then it is referred to as a case of discrepancy at the base station. The proposed system block diagram is shown in Figure1. 


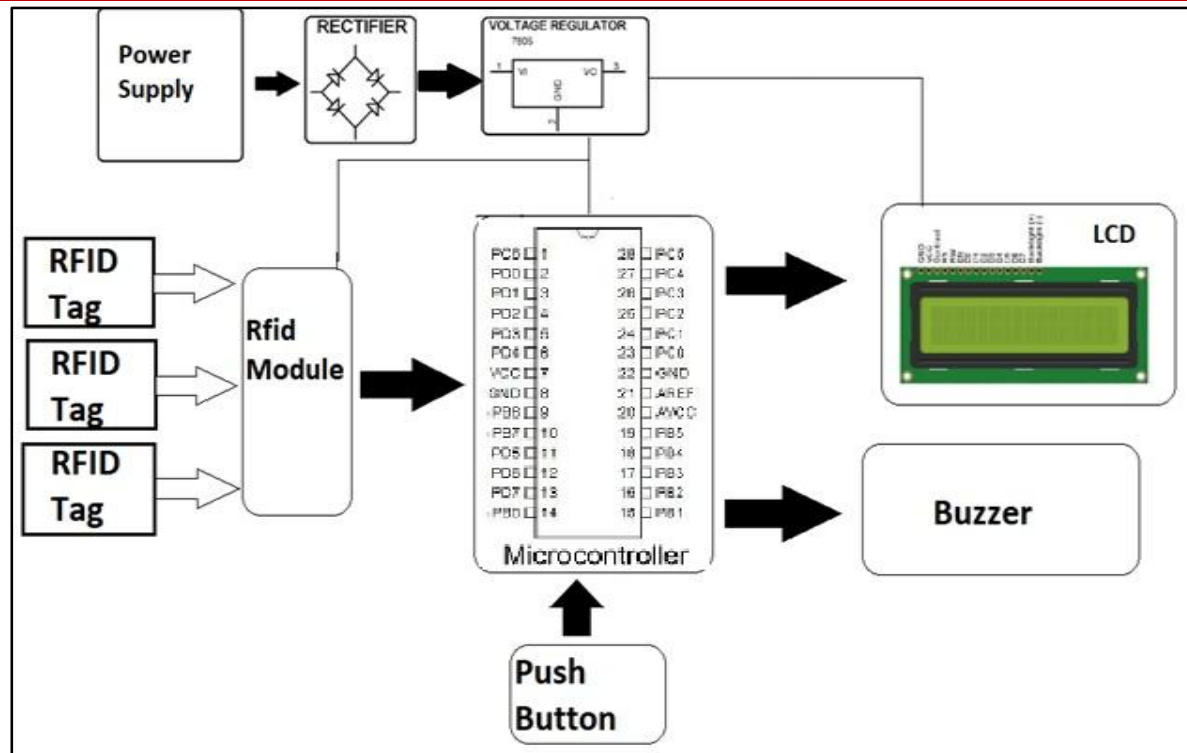

Fig-1: Proposed System Block Diagram

\section{Research Gap}

Most developed trolleys are developed using traditional line following methodology. Since this some supermarkets have no way to use this technology it's difficult to use the line following technique in the whole supermarket. Furthermore, tracking the purchased goods in the trolley and billing system with help of android mobile device fixed to the trolley. Most of the researchers are developed to track the purchased goods but few trolleys perform both aspects goods tracking and automatic billing.

\section{Challenges in the Present System}

There still exists a smart trolley system in which the user has to go through the shopping process through it, but the major problem with it is, it is not fully automated.

Major challenges in the present system is:

- The trolley is not fully automated.

- Auto billing system is not there in the existing system.

- The item removed from the cart is not automatically removed from the bill.

- Does not give the information about the product validity.

- Interface is not user friendly.

- Payment option is not provided.

- Security

Since the cart is not fully automated, customers need to manually remove all the products which they don't want. The Bill amount is not generated in the system with proper details of the product. Interface used in the existing system is not user friendly. Not everyone can easily deal with the embedded system until it's displayed properly. Payment option is not there in the existing system, users cannot pay through their phone itself and thus the existing system is of no use because at the end we need to go for a queue and pay the amount, which weakens the system.

\section{Advantage of Proposed System over the Existing System}

The major challenges of the existing system are resolved in the proposed system, and the major advantages are listed below:

- Cart is fully automated.

- Auto billing system is there in the proposed system.

- The item removed from the cart is automatically removed from the bill with the use of image recognition and weight sensors.

- Information about the product validity and other features are included in the proposed system.

- Interface is user friendly

- Payment option is provided, different platforms like upi, card, or else through online platforms like paytm, mobikwik e.t.c.

- Tracing of the cart can be done, using GPS

- Security of the cart is monitored.

\section{Proposed System Modules \\ Basic Module}

Basically to ensure automation of the system, the customer will initiate the process by clicking on a 'START BUTTON' and followed by scanning the product. A scanner is connected to the base station 
located at the payment counter. When a customer scans a product, all the information such as and name of the product is displayed while the weight of the product is stored in the database. It uses NFC technology combined with RFID in the scanner that detects the bar code and sends the information to the supermarket database.

The application keeps adding the items and computing the cost and the list is updated accordingly. There is an option for a customer to remove the product again by rescanning it. A load cell, which is basically a load sensor is located on the trolley helps in decision making against abnormal activities and discrepancy. At the counter, cashier enters the customer order id to check the order details and payment details. Cashier then enter payment amount and fill all the required information and then proceed for payment. Once the payment process is done, data will be updated in database and receipt will be printed, it will reduce the long waiting queue in front of the counter, thus saving the time of customers for a very enjoyable shopping experience.

\section{Security Module}

Beside many other functions, Smart Trolley ensures security measures by considering special cases and giving its solutions.

These cases are mentioned below:

- A customer forgets to keep a product into the trolley after scanning it.

- A customer scans one product but places multiple products in the trolley.

- A customer attempts to take away products in the trolley without scanning them.

- A customer changes their mind and removes the product from the trolley.

- A customer scans a cheaper product and places the expensive product having the same weight.

The design of the product carefully considers all these cases, which are mentioned above. Basically to ensure automation of the system, the scanner is connected to the base station located at the payment counter. When a customer scans a product information such as price and name of the product is displayed while the weight of the product is also stored in the database against all barcodes. Weight of products is an important factor to double check the identity of a product to protect against discrepancy or dishonest activity [10]. A load cell, which is basically a weight sensor, is located at the bottom of the Smart Trolley. The output of the load cell helps in decision making against abnormal activities. For example, if the weight of the product measured by the load cell is not matching with the actual weight of the product then it is referred to as a case of discrepancy at the base station [11].

\section{Payment Methods and Receipt Generation}

Payment method allows users to complete their purchases from the Smart Trolley. The present payment system on the tills and self-service checkout as well as cash payment .The self-checkout can be enabled by UPI payments. The user gives his UPI details and a dynamic QR code will be generated for his amount and then he can pay using any UPI application. For cash payments, the bill is already generated and is sent to the store's database, and then retrieved by the cashier using cart id and the respective amount can be collected from the customer [12, 13].

\section{Experimental Setup}

In the Proposed system each product is attached with the RFID Tag and when an RFID reader reads the RFID Tag the information is transmitted to the Microcontroller and it connect local server data base. The RFID tag number is compared with the existing data base if the information is available the product data is retrieved from the data base and transmits the details of the product on the LCD screen. This process is repeated till the end of the shopping. After the customer finishes the shopping he use to press the completion of shopping button which is incorporated in the Smart Cart then the total number of products he had placed in the cart and amount of final shopping list will be displayed in the screen. The total list of the Smart Cart with the unique code transmitted to the main PC with help of $\mathrm{Wi}-\mathrm{Fi}$ module which is placed in the SC $[14,15]$.

\section{Hardware Requirements}

- ATmega 328P Microcontroller: 8 bit microcontroller based on AVR RISC architecture.

- EM-18 RFID module: Low frequency RFID reader.

- RFID cards: RFID cards are helpful for identifying and sensing labeled people and items for access control, automation, and also a complete assortment of various applications.

- LCD: Data to be displayed on the LCD.

- Resistors: The resistor is a passive electrical component to create resistance in the flow of electric current.

- Capacitors: The capacitor is a component which has the ability or "capacity" to store energy in the form of an electrical charge producing a potential difference (Static Voltage) across its plates, much like a small rechargeable battery.

- Push Button: A push-button (also spelled pushbutton) or simply button is a simple switch mechanism for controlling some aspect of a machine or a process.

- Crystal Oscillator: A crystal oscillator is an electronic oscillator circuit that uses the 
mechanical resonance of a vibrating crystal of piezoelectric material to create an electrical signal with a precise frequency. This frequency is often used to keep track of time.

- Diodes: A diode is a two-terminal electronic component that conducts current primarily in one direction (asymmetric conductance); it has low (ideally zero) resistance in one direction, and high (ideally infinite) resistance in the other.

- PCB: A printed circuit board (PCB) mechanically supports and electrically connects electronic components or electrical components using conductive tracks, pads and other features etched from one or more sheet layers of copper laminated onto and/or between sheet layers of a non-conductive substrate. Components are generally soldered onto the PCB to both electrically connect and mechanically fasten them to it.

- LED's: A light-emitting diode (LED) is a semiconductor light source. LEDs are used as indicator lamps in many devices, and are increasingly used for lighting.

- Transformer/Adapter: A transformer is a static electrical device that transfers electrical energy between two or more circuits.

- AC adapter, AC/DC adapter, or AC/DC converter is a type of external power supply, often enclosed in a case similar to an AC plug.

\section{Software Requirements}

- Arduino IDE written in java is used to upload programs on the arduino board.

- Easy to Program and Use and Efficiency in embedded development and embedded learning.

- The Arduino IDE supports the languages $\mathrm{C}$ and $\mathrm{C}++$.

- The executable code is then loaded on the board by a loader program in the board's firmware.
Flow chart for the Proposed System

Flow chart of whole proposed system

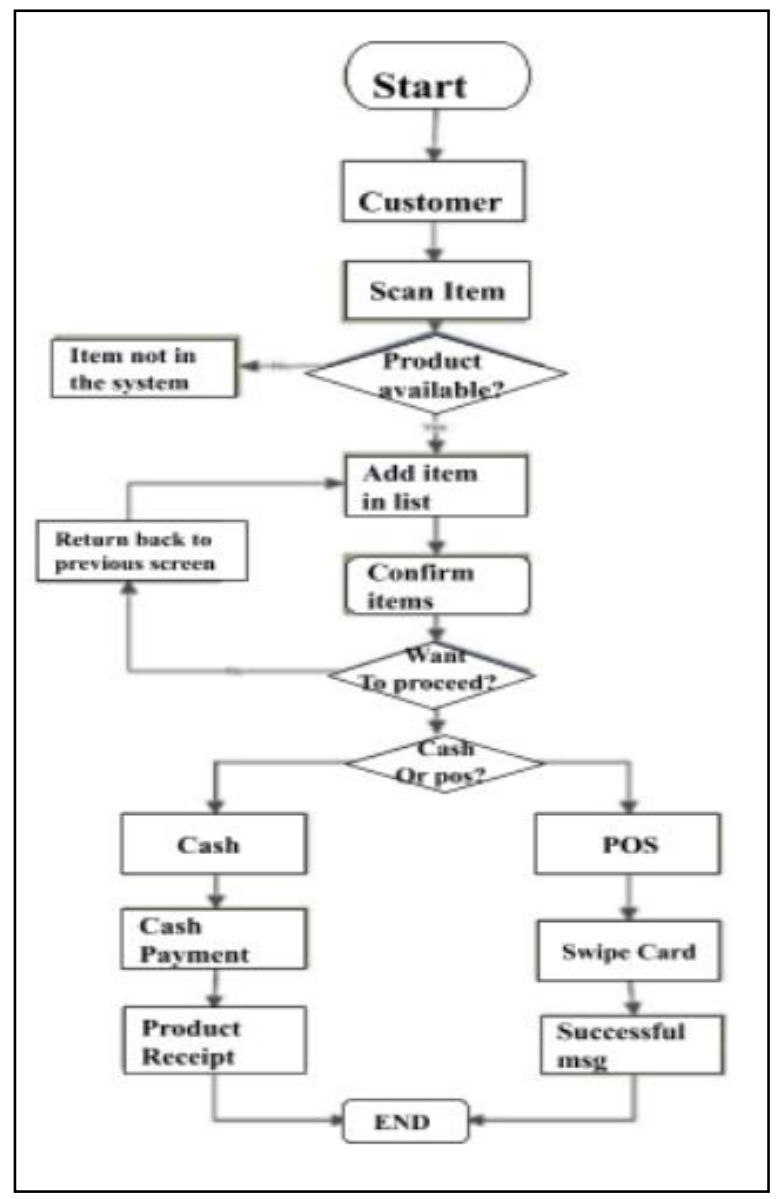

Fig-2(a): Flowchart for Customer or User

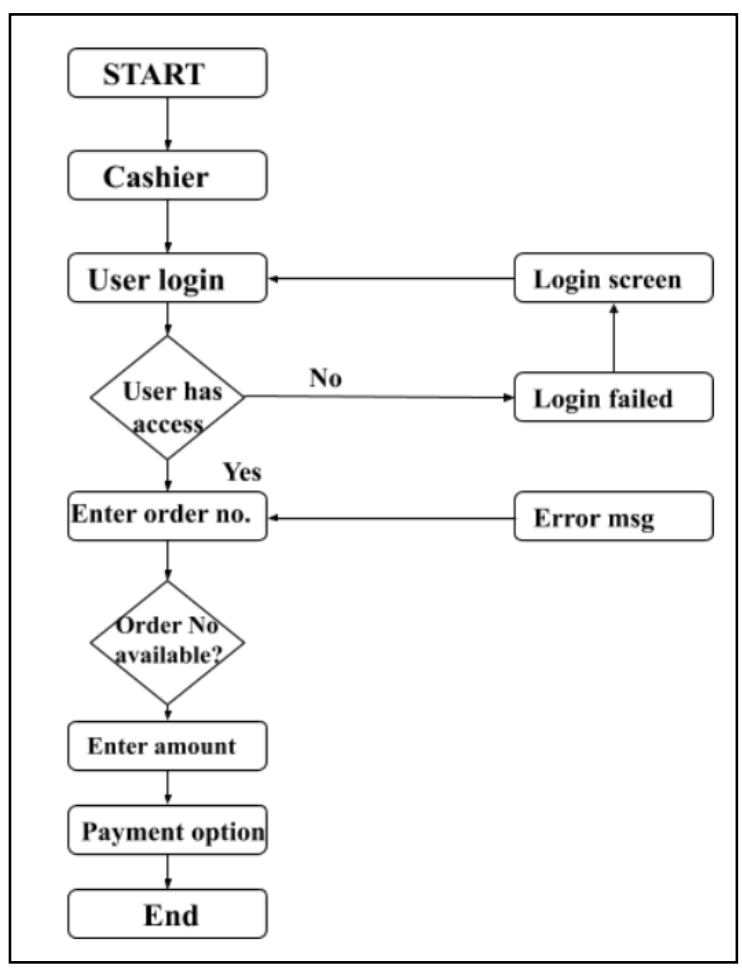

Fig-2(b): Flowchart for Cashier 


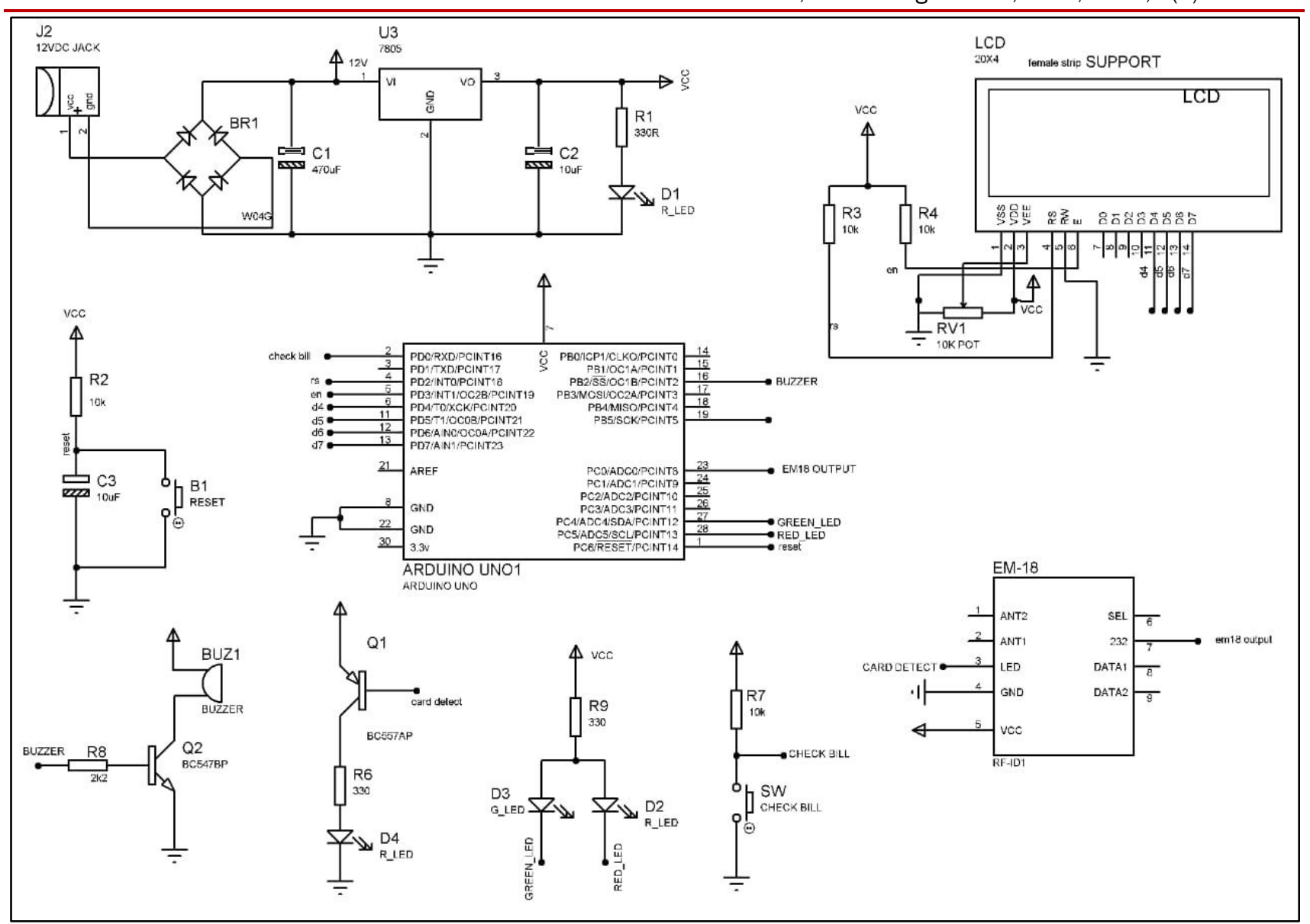

Fig-3: Circuit diagram for the developed system

\section{Algorithm}

Step1:-Take a trolley.

Step2:-Start placing the items u want.

Step3:-The items placed in the trolley scanned automatically.

Step4:-The scanned items will now display on the lcd.

Step5:-If item is not in the store it will display

Step 6:-Place all the items you want.

Step 7:-Click proceed, Bill generated

Step 8:-You will be redirected to the payment page

Step 9:-Choose the payment option and pay.

Step 10:-End shopping

\section{CONCLUSION}

This paper discusses the easiness of using a smart trolley and eradicating the traditional way of shopping. If this smart system is implemented in hypermarkets, it will reduce the long waiting queue in front of the counter, thus saving the time of customers for a very enjoyable shopping experience. It reduces time by using RFID Technology and improves utilization of resources like manpower. The location of the shopping trolley and items, can be tracked easily by using the RFID technology localization scheme and Android application. Both communicate via the Bluetooth function. A weight sensor is placed at the bottom of the trolley to provide security and transparency. In the payment module, the customers get several options like UPI payment, cash or card.

There is some room for further improvement of the project. Firstly, the mechanism of the robot should be enhanced and designed in a simpler way, to ease the installation under a shopping trolley. Secondly, a more advanced algorithm should be developed so that the shopping trolley is able to move in a crowded environment and follows the user automatically in any direction. Lastly, an improved Android application that can remind the users of the items they need to purchase when they are unintentionally passing by the goods location. In addition, it can also remind the users who have health problems about the nutrition of products. Besides that, the locations of shopping trolleys are tracked and can be displayed to allow supermarket staff and users to know the shopping trolley current locations.

\section{ACKNOWLEDGEMENT}

Firstly, we highly indebted to the Department of Electronics \& Communication Engineering for giving us the opportunity to complete this research work. We sincerely express our sincere gratitude and deepest appreciation to Dr. Rajeswari, Professor, HoD of ECE and Principal of Acharya Institute of Technology, Bangalore, Karnataka, for guiding and 
encouraging us to develop and simulate the control designs essential for this work and support. We would like thank to Mr. Devasis Pradhan, Assistant Professor, Dept. of ECE, for guiding us throughout the course of our project through which the project work come into a streamline work and we also thankful to our beloved parents for their trust on us and their believe.

\section{REFERENCE}

1. Machike, K., Golait, M., Rathod, R., Petkar, R., \& Goche, P. (2017). A new technology of smart trolley using RFID and ZIGBEE. International Journal on Recent and Innovation Trends in Computing and Communication, 5(2):256-259.

2. Thiyagarajan, M., Aejaz, M., \& Kumar, M. (2017). RFID based advanced trolley for super market.

3. Prasad, J. S., Kumar B. O. P., Roopa, D., \& Arjun, A. K. (2011). A novel low-cost intelligent shopping cart. IEEE $2^{\text {nd }}$ International Conference on Networked Embedded Systems for Enterprise Applications, 1-4.

4. Karpagam, V., Balapriya, S., Kalairubini, G., \& Kalaivani, A. (2017). Smart trolley with smart billing. International Journal of Computer Systems, 4(3):55-58.

5. Dhavale Shraddha, D., Dhokane Trupti, J., \& Shinde Priyanka, S. (2016). IOT based intelligent trolley for shopping mall. Int. J. Eng. Dev. Res, 4(2), 1283-1285.

6. Sainath, S., Surender, K., Arvind, V. V., \& Thangakumar, J. (2014). Automated shopping trolley for super market billing system. International Journal of Computer Applications, 3, 7-8.

7. Jadhav, R. S., Avale, P. N., Tarali, S. V., \& Pawar, S. (2015). U. RFID based Automatic Billing Trolley. International Journal for Scientific Research \& Development, 3(2):2297-2299.

8. Kumar, N., Pal, N., Kumar, P., \& Kumari, A. (2018, March). Impact of different inertia weight functions on particle swarm optimization algorithm to resolve economic load dispatch problems. In 2018 4th International Conference on
Recent Advances in Information Technology (RAIT) (pp. 1-5). IEEE.

9. Popoola, S. I., Popoola, O. A., Oluwaranti, A. I., Atayero, A. A., Badejo, J. A., \& Misra, S. (2017, October). A cloud-based intelligent toll collection system for smart cities. In International conference on next generation computing technologies (pp. 653-663). Springer, Singapore.

10. Oguntosin, V. W., Nasuto, S. J., \& Hayashi, Y. (2015, March). A compact low-cost electronic hardware design for actuating soft robots. In 2015 17th UKSim-AMSS International Conference on Modelling and Simulation (UKSim) (pp. 242-247). IEEE.

11. Agbetuyi, A. F., Orovwode, H. E., Awelewa, A. A., Wara, S. T., \& Oyediran, T. (2017). Design and implementation of an automatic irrigation system based on monitoring soil moisture. Journal of Electrical Engineering. 16(2):206-215.

12. Matthews, V. O., Osuoyah, Q., Popoola, S. I., Adetiba, E., \& Atayero, A. A. (2017). C-BRIG: a network architecture for real-time information exchange in smart and connected campuses. World Congress on Engineering, WCE 2017; Imperial College London; United Kingdom; 2229:398-401.

13. Awodeyi, A., Adekunle, I. S., Akindele, A. E., \& Victor, M. (2018). Design and Construction of a Microcontroller Based Automated Intelligent Street Lighting System. International Journal of Scientific and Engineering Research, 9(5), 23022308.

14. Akindele Ayoola, E., Awodeyi Afolabi, I., Matthews Victor, O., Alashiri Olaitan, A., Idowu Oriyomi, K., \& Olaloye Folarin, J. (2018). Development of an Electronic Weighing Indicator for Digital Measurement. International Research Journal of Engineering and Technology,5(9), P19-25.

15. Awodeyi Afolabi, I., Moses, O., Makinde Opeyemi, S., Ben-Obaje Abraham, A., \& Abayomi-Zannu Temidayo, P. (2018). Design and Construction of A Panic Button Alarm System for Security Emergencies. International Journal of Engineering and Techniques, 4(3). 